переводческой трансформации как калькирование, так как фамилия Baggins произошла от английского «bag», что в переводе означает «сумка». Также мы наблюдаем элемент переводческой транслитерации, поскольку окончание фамилии -ins (-uнc) сохранено переводчиками.

Пример №3. Оригинал на английском языке - WatcherintheWater

Перевод 1 - Глубинный страж. При переводе данного антропонима применяется такая переводческая трансформация как целостное преобразование (Watcher in the Water - Глубинный страж. Также мы наблюдаем такой прием перевода как калькирование, так как «watcher» в переводе с английского обозначает «страж, сторож». Перевод 2 - Страж озера. Переводчики №2 решили перевести данное имя с помощью такого приема как конкретизация. water - вода, водоем, но авторы перевода решили конкретизировать, что именно озеро, а не какой-либо другой водоем. Также мы видим, что слово «watcher» переведено с помощью калькирования - «страж». В целом, при анализе способов передачи мужских имен, было выявлено, что наиболее частой переводческой трансформацией является транскрипция, женские имена в рассматриваемом романе переводятся в основном с помощью переводческой транслитерации.

1. John Ronald Reuel Tolkien "The Lord Of The Rings"

2. Гюббенет И. В. Основы филологической интерпретации литературно-художественного текста. Издво МГУ, 1991. - 64 с.

3. Ермолович Д. И. Имена собственные на стыке языков и культур. - Изд-во «Р. Валент», 2001. - 198 с.

4. Кузнецов С. А. «Большой толковый словарь русского языка»-Изд-во «Норинт», 2014. - 37 с.

5. Ренц Т. Г., Рыцарева А. Э. «Словарь лингвистических терминов на английском языке». - Изд-во «Либроком», 2006. - 43 с.

6. Суперанская А.В. Общая теория имени собственного. - Изд-во «Наука», 1973. - 367 с.

7. Толкин Дж. Р. Р. «Властелин колец» в переводе В. С. Муравьева, А. А. Кистяковского.

8. Толкин Дж. Р. Р. «Властелин колец» в переводе Н. В. Григорьевой, В. И. Грушецкого.

9. Фонякова О. И. «Имя собственное в художественном тексте». - Изд-во «ЛГУ», 1990. - 103 с.

\title{
Одинцова Т.Ю., Чмых И.Е. \\ Стилистический аспект перевода средств экспрессии (метафоры, фразеологизмы, эпитеты) на основе романа Сомерсета Моэма «Театр»
}

Сургутский государственный университет (Россия, Сургут )

doi:10.18411/spc-22-03-2018-18

idsp: 000001:spc-22-03-2018-18

\section{Аннотация}

В статье рассматриваются стилистические особенности перевода средств экспрессии английского языка и их перевода на русский язык. Материалом данной работы послужил роман Сомерсета Моэма «Театр» и его перевод на русский язык, выполненный Галиной Островской.

Ключевые слова: метафора, фразеологизм, эпитет, средства экспрессии.

\section{Annotation}

The given article deals with the translation problem of means of expression The material under analysis is Somerset Maugham "Theatre" and its translation done by G Ostrovskaya. The necessity of using transformations is clearly stated.

Key words: metaphor, idioms, epithets, means of expression.

Одним из основных и наиболее интересных для изучения в переводческой теории является стилистический аспект при переводе на иностранный язык. Данный 
аспект изучается лингвистами, но не рассмотрен в полной мере. Стилистический аспект при переводе довольно важен, так как существует необходимость передачи средств экспрессии, заложенных автором в текст оригинала.

Перевод - это преобразование сообщения на исходном языке в сообщение на языке перевода. Перевести - значит выразить верно и полно средствами одного языка то, что уже выражено ранее средствами другого языка (А.В. Федоров, 1968 г.). Проблемой перевода выразительных средств занимались такие видные ученые как И.В. Арнольд, Л.С. Бархударов, С.И. Бухтияров, А.Н. Веселовский, Н.К. Грабовский, В.Н. Комиссаров, Я.И. Рецкер, В.С. Слепович и др.

Опытный переводчик старается использовать стилистические приемы, использованные в оригинале, чтобы максимально передать яркость и экспрессивное воздействие на читателя, которое хотел создать автор оригинального текста. Переводчик может использовать два способа: полностью скопировать стилистическое средство оригинала или подобрать средство, которое сможет максимально точно создать эмоциональный эффект на читателя. Это есть прием стилистической компенсации, то есть не всегда правильно передать «метафору-метафорой», а необходимо передать «любовь-любовью», то есть эмоциональный аспект. Для переводчика важно передать не столько форму, сколько функцию стилистического приема, что может подразумевать некую свободу действия: например, лексические средства можно передавать грамматическими и так далее.

При передаче стилистических приемов (метафор, эпитетов, сравнений, аллюзий, пословиц и т.д.) переводчику необходимо понять, будет ли правильно сохранить данную стилистическую фигуру, или все же необходимо заменить ее. Причинами замены могут являться особенности сочетаемости слов языка ПЯ, их употребление и национальные особенности стилистических систем разных языков.

Английский язык, как и другие языки, имеет насыщенную и длинную историю, в ходе которой сложилось немалое количество «крылатых» выражений, ставшие довольно популярными и широко употребляемыми народом. Так и появился уникальный и своеобразный слой языка - фразеология, которая является совокупностью уникальных выражений, имеющих самостоятельное значение.

Перевод является своего рода искусством, так при переводе фразеологических единиц, переводчику необходимо отразить его образность, не упустив их стилистическую функцию. При отсутствии полного эквивалента в языке, переводчику необходимо искать приблизительные соответствия, не искажающие смысл и семантику данной языковой единицы.

Хорошее знание фразеологии обоих языков, позволяет переводчику из «авторских трансформации» восстановить оригинальные фразеологизмы и передать при переводе заложенную в них экспрессивность. Таким образом, существуют несколько видов передачи фразеологических единиц на другие языки:

- Фразеологическая единица имеет эквивалент в переводном языке, абсолютно идентичный по значению и семантике, переводится эквивалентом (as cold as ice - холодный как лед) [3];

- Фразеологизм может быть передан с неким отступлением от перевода, то есть фразеологизм исходного языка лишь приблизительно равен фразеологизму переводного языка, переводится аналогом (a drop in the bucket - капля в море) [3];

- Фразеологизм не имеет ни эквивалентов, ни аналогов в языке перевода, то есть фразеологизмы двух языков не являются равными, в таком случае переводчику необходимо использовать нефразеологический перевод (to burn candle on both ends - работать с утра и до позднего вечера) [3].

Рассмотрим некоторые примеры из романа С. Моэма «Театр»:

Пример 1. Текст оригинала: "He told me he never expected a theatre to be run on such businesslike lines”. Текст перевода: «Он не представлял себе, что можно поставить 
театр на деловые рельсы». При переводе данного фразеологизма был использован такой способ перевода лексической единицы, как калькирование. Автор использует данный прием для того, чтобы донести читателю идею и эстетический смысл, заложенный автором. Также, одним из наиболее важных и ярких средств выражения экспрессии является эпитет.

Эпитет - троп лексико-синтаксический, так как он выполняет функции обстоятельства, определения или обращения. Отличается необязательно переносным характером выражающего его слова и обязательным наличием эмотивноэкспрессивных коннотаций, благодаря которым и выражается отношение автора к предмету [1]. Именно такое определение данному средству экспрессии дает И.В. Арнольд. Для адекватной передачи эпитета с языка оригинала на русский язык обычно используются следующие способы перевода, выделенные Т.А. Казаковой:

1) Калькирование (shiny black hair - блестящие черные волосы);

2) Описательный перевод (with a ladylike cough - как умеют кашлять только истинные леди);

3) Нулевойперевод (the strange new visitor - гость) [2].

Пример 2. Текст оригинала: "She forced a smile to her ashy lips". Текст перевода: «Бескровные губы шевельнулись в вымученной улыбке». В данном текстовом фрагменте переводчиком были использованы такие лексические переводческие трансформации, как калькирование и целостное преобразование. Слово "lips" было передано дословно, а вот, что касается "ashy", переводчик полностью заменил это слово для придачи большей экспрессивности в тексте перевода. При этом Галина Островская сохранила лексическую и синтаксическую структуру предложения.

Еще одним, не менее важным, средством выражения экспрессии является метафора. Данный троп очень популярен в художественной литературе, так как является одним из наиболее эмоционально окрашенных. Метафора - одна из важнейших средств выражения экспрессии. С.И. Ожегов в толковом словаре называет метафорой: 1) вид, тропу; 2) скрытое образное уподобление. Метафорой, по определению М. Джонсона, можно назвать любое словосочетание, используемое в переносном значении [4]. Можно выделить следующие способы перевода метафор, которые выделяет Т.А. Казакова: калькирование; эквивалентный перевод; описательный перевод [2].

Пример 3.Тексторигинала: "How dare you, old cow, interfere with my private concerns?”. Текст перевода: «Вы, старая корова, кто вам позволил совать нос в мои дела?».

В предложенном переводе метафоры можно отметить использование такой лексической переводческой трансформации как калькирование. Очевидно, что обращение к пожилой женщине «старая корова», как в переводном языке, так и в языке оригинала несет отрицательную коннотацию, именно поэтому использование калькирования уместно.

В заключении, можно отметить, что нами было выявлено три средства выражения экспрессии (фразеологические единицы, метафоры и эпитеты), которые вызывают наибольшие трудности в современном переводоведении.

$$
* * *
$$

1. Амосова, Н.Н. Основы английской фразеологии / Н.Н. Амосова - М.: Изд-во Ленинградского университета, 1989. - 208 с.

2. Арнольд И.В. Стилистика современного английского языка (стилистика дискурсов) - Л., 2005, - 154 c.

3. Виноградов, В.С. Введение в переводоведение (общие и лексические вопросы) / В.С. Виноградов. - М.: Издательство института общего среднего образования РАО, 2001. - 224 с.

4. Джонсон М. Метафоры, которыми мы живем. Теория метафоры. Пер. Н.В. Перцова. М., 2007. - 256 c. 